tion and Copious Explanations, by Collyns Simon, LL.D., author of "The Nature and Elements of the External World," and Proposer of the Berkeleian Prizes in 1848 and 1850 .

A NEW book on Ferns has just made its appearance at Salem, Massachusetts, under the title of "Ferns in their Homes and Ours." Its author is Mr. J. Robinson, Professor of Botany, Massachusetts Horticultural Society, and the book forms one of a series called the "American Natural History Series." It has been put together especially for the use of persons residing in the United States, but the author has nevertheless made himself thoroughly acquainted with the works of European pteridologists and pays a high tribute to those of our own country, notably the more recent works of the veteran John Smith. Though the book commences with a consideration of the life-history of a fern, classification, distribution, and nomenclature, it is for its practical part, dealing with the selection and cultivation of these favourite plants in living, that the book will be most valued.

NEws from Denmark states that the last pillar of the first fixed bridge across the Lim Fjord has now been finished; the new bridge will connect Aalborg on the south side of the fjord, with Norresundby on the north, and it is hoped that it will be opened for traffic during the autumn. Our readers will remember that the $\operatorname{Lim}$ Fjord is an arm of the sea stretching right across the Danish continent from east to west.

SOME interesting excavations have been recently made at the "Limburg," a large ruin near Dürkheim in the Bavarian Palatinate, at the instigation of the German Anthropological Society. During 1877 prehistoric remains had been found at this spot, and the work being continued this year, numbers of urns, human and animal bones were discovered, all undoubtedly of prehistoric origin. The most interesting part of the discovery is the laying bare of a cremation ground.

A PAPER on "The Salt Lakes, Deserts, and Salt Districts of Asia," by Mr. Thomas Ward, read before the Liverpool Literary and Philosophical Society has been published separately, with a map. The author endeavours to illustrate from what is known to be going on in the formation of salt at the present time, the way in which salt was formed in past ages.

The Rev. Thomas Powell, of Upolu, Samoa, writes us that in vol. xv. of NATURE, p. 503, in our report of the Linnean Society, his paper on "Poisoned Spears and Arrows" is represented as having reference to Samoa. Mr. Powell sends us a corrected copy of the paper from which we see that the paper has reference to the New Hebrides. The Samoans, Mr. Powell states, have no such custom as the use of poisoned weapons of any kind. They formerly made use of the bow and arrow, not, however, for purposes of war, but of sport.only. The introduction of fowling-pieces has abolished the use of the bow. Another error, Mr. Powell writes, into which we have been led is the statement that Callophyllum inophyllum was among the trees whose milky juice was used as a poison. This is not $\mathrm{Mr}$. Powell's statement. His informant said that the T'oto resembled that tree in general appearance. The $C$. inophyllum is a valuable timber tree in common use. Its flowers and fruit are used in Samoa as a perfume. From its fruit an oil is extracted in Fiji, which is useful as a liniment in rheumatism.

THE additions to the Zoological Society's Gardens during the past week include a Banded Ichneumon (Herpestes fasciatus) from West Africa, presented by Mr. F. T. Blackley; two Vinaceous Turtledoves (Tutur vinaceus) from West Africa, a Greek Land Tortoise (Testudo graca), European, presented by Miss Harris ; a Common Adder (Vipera berus), European, pre. sented by the Viscount Mandeville; a Spotted Turtledove (Turtur auritus), bred in the Gardens.

\section{A FOSSIL PLANT}

M ANY years ago the late Sir William Logan drew attention to the occurrence of fossil plants in the Devonian strata of Canada, and Prof. J. W. Dawson, F.R.S., in the Quarterly Fournal of the Geological Society, in vols. xv. and xviii., described and figured some of these specimens. Amongst them was a plant which he designated Psilophytum. Dr. S. S. Scoville has since discovered the remains of plants in the lower silurians at Longstreet Creek, near Lebanon, Ohio, which Prof. Newberry considered as the casts of some large fucoids or marine plants. Count Saporta has found the branch of a fern in the silurian schists or slates of Angers, France. Prof. Leo Lesquereux, to whom we owe so much for his labours in inves. tigating the fossil plants of the United States, in a paper read before the American Philosophical Society, October 10, 1877, has described and figured a plant from the lower Heldeberg sandstone, Michigan, under the name of Psilophytum cornutum.

In a paper read by myself before this society on December 26 , r876, I stated that after some years' search I had not been able to find the Palcochorda major mentioned by Professors Harkness and Nicholson as occurring in the Manx schists in such a state of preservation as to be certain of its true nature, but $I$ had a fucoid in my possession found by Mr. Grindlay in the drift near Laxey.

As Mr. Lesquereux's specimen so much resembles the one found at Laxey I shall give his description at length.

"Stem thick, dichotomous, divisions variable in distance, the

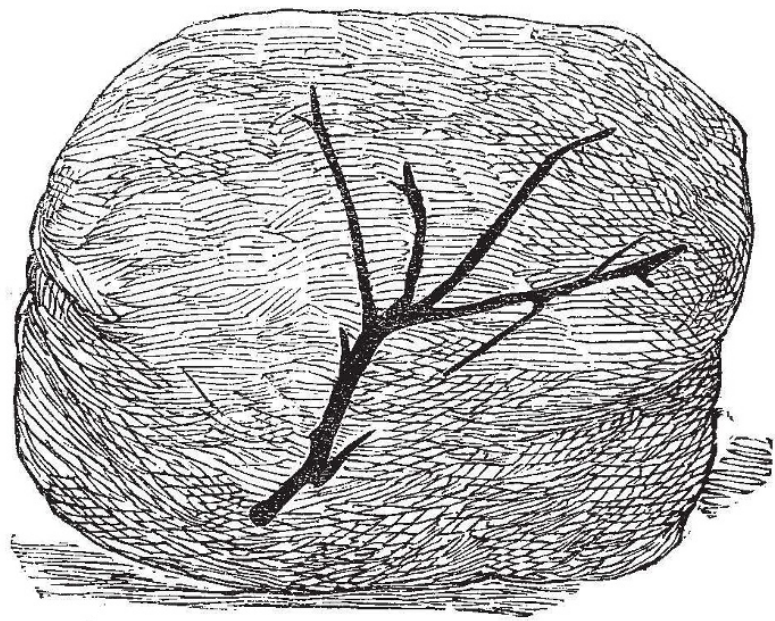

terminal ones short, pointed nearly equal in size and length, surface slightly rugose and irregularly striate.

"The branches in the lower part are thick comparatively to their length, three or four millimetres, irregularly striate when decorticated, or merely punctuate upon the thin bark with small projecting dots resembling the basilar remains of scales or small decayed leaves; lateral branches short, narrowed to a sharp point; the upper or terminal ones about equal in length, appear. ing like a pair of pointed horns."

The species is only comparable to some of the fragments not specified but figured by Prof. J. W. Dawson (Geol. Survey of Canada, Fossil Plants of the Devonian and upper silurian formations, Figs. 243, 244). The author remarks "that these fragments are probably originating in the upper silurian of Gaspé; that as they are found in the lower part of the limestone which underlies the Devonian Gaspé sandstone and become more abundant in the upper beds, this suffices to indicate the existence of the neighbouring land, probably composed of silurian rocks and supporting vegetation."

From the preservation of its branches even to the smallest sub. divisions, the specimens here represent part of a plant embedded in the place of its growth. The matrice is a piece of very hard calcareous shale seven to eight millimetres thick, bearing on one side irregular undulations like ripple marks, without any trace of organic remains, and on the other the fragments of plants asfigured here. The branch in $(a)$ represents a different species, 1 " Notice of a Fossil Plant found at Laxey, in the Isle of Man," by E. W. Binney, F.R.S., F.G.S., President, paper read at the Literary and Philosophical Society, Manchester. 
and indeed a marine or rather a brackish plant, closely related to the species of the present genus Chorda, Stack. This fragment seems to have been mixed in the tide pools with fresh water or land plants growing there. For another thick specimen of the same locality and compound bears a profusion of marine mollusks, and has only branches of this as yet undescribed marine species, Calamophycus septus.

Habitat lower heldeberg sandstone, Michigan, discovered and comamunicated by Dr. Carl Rominger (State Geologist).

On comparing my Manx specimen, which was found on the surface in a field at Laxey with that figured and described by Prof. Lesquereux, it agrees with the latter in every respect, except that strix and scales are not observable on the stem. The stem is thick, dichotomous; divisions variable in distance, the terminal ones short, pointed nearly equal in size and length, surface nearly smooth. The branches in the lower part are thick comparatively to their length. The surface of the stem appears to be smooth and affords no evidence of strix or scales.

The woodcut on the preceding page represents the specimen a little over the natural size.

The stone in which the plant is embedded is a fine-grained grit of a grey colour, and the specimen itself is of a yellow tint as if coloured by oxide of iron; it runs nearly at right angles to the bedding of the stone, and appears as if standing in the same position as it had grown. The stone is a rolled one but it is evidently from the Manx schists found in the vicinity. These, according to Profs. Harkness and Nicholson, are of the age of the Skiddaw slates, but the rock in which the fossil occurs may be of older date, as some of the lower portions of the series have not yet been clearly determined; so here we have evidence of a plant in the lowest part of the silurian formation, or even lower. By diligent search the rock in which the specimen occurs may probably be found in sitî in the upper part of the Laxey valley. The great resemblance, if not the identity, of the Manx with the $\Lambda$ merican specimen is very remarkable, and shows the similarity of conditions then prevailing in distant parts of the globe. The specimen might have been called Psilophytum cormutumn, if any marking on the surface of the stem had been observed, but as these appear to be absent it is proposed to call it Psilophytum monense. As to the nature of the water in which it grew there is no evidence from organic remains, but its characters resernble those of a fucoid more than a land plant.

\section{THE FIGURE AND SIZE OF THE EARTH}

THE portion of the earth's surface bounded by the horizon which one is able to take in at one view, is but seldom a regular plane; more generally heights and depressions, mountains and valleys, alternate with each other so irregularly, that at first nothing seems farther from reality than the idea of a regular form of the earth's surface. But the more our point of view overtops the mountains which lie within the horizon, the further obvisusly will our range of view extend, and all the mountains and valleys which give so irregular a form to the horizon of the plain will, under this condition, become imperceptible and unimportant. Indeed, one can easily conceive that if the eye were able to comprehend at one time a much greater portion of the surface, the irregularities of the plain caused by the mountains and valleys would appear exceedingly small in comparison with the extent of surface. But such considerations must also have occurred to the ancients; for the earliest conception among the Greeks of the form of the earth's surface was that of a flat disc surrounded by the river Okeanos, into which the sun plunged nightly. The first advance was made by Thales, who said the earth must have a point of support, and imagined it was borne by the water. Anaximenes supposed that a strong dense atmosphere supported the earth. Quite another idea prevailed in India, where the earth was believed to be borne on the back of an elephant. More correct views of the figure of the earth prevailed at an earliex period in other parts of the East, in Egypt and a part of Asia. The Egyptians and Chaldeans taught at the earliest period the spherical form of the earth, and Pythagoras appears to have adopted this idea from them.

This difference of conception need not, however, be wondered at when we remember that the Greeks seldom undertook long journeys, and knew of the lands outside Greece only from fabulous narratives. It was otherwise with the people of the East, who, through their frequent and extensive travels, learned at an early period to know the positions of the stars as guides,

I From a series of papers in Die Natur, by Karl Maria Friederici. and attained to a more correct conception of the size and form of the earth. The Chaldæans already knew the circumference of the earth so nearly that they said a good walker would take three years to walk round it.

Eudoxus was the first in Greece to recognise a symmetrical curvature of the earth's surface. He had noticed on long journeys that stars which at their greatest height (culmination) stood near the horizon gradually diminished in altitude, and finally disap. peared; but on his return to those regions they again gradually became visible and assumed their previous altitudes. The cir. cumstance that these altitudes of the stars changed regularly in proportion to the length of way travelled, led him to the conclusion of a regular curvature of the earth's surface. 'This conclusion being accepted, a simple method was indicated for measuring the circumference of the terrestrial sphere. For suppose a star reaches at a place, $A$, at its maximum a height of seven degrees above the horizon, if the observer move to another place, $B$, lying to the north, but in the same geographical longitude as $\mathbf{A}$, and measure again the highest altitude of the same star, say six degrees; then the distance of the place $A$ from $B$ is equal to the $360 t h$ part of the whole circumference of the earth. Let the distance between $\mathrm{A}$ and $\mathrm{B}$ be now measured, and it will be found to be sixty-nine English miles; thus the entire circumference of the earth would be $69 \times 360=$ about 25,000 miles.

Aristotle inferred, from physical and especially hydrostatic considerations, that the earth was spherisal, since, he said, the water, which formed the larger part of the upper stratum of the earth, sought, by virtue of its weight and the mobility of its molecules, to approach as near as possible to the centre of the earth, it sought to assume the lowest position, and could never be in equilibrium until all parts of its surface were equidistant from the centre of the earth, i.e., formed a globular surface. This interence, near as it comes to the truth, was yet in Aristotle's time only an unproved hypothesis; the existence of a centre exerting attraction in all directions was first recognised as probable at a much later period, Newton being the first to publish the conception.

The theory according to which the earth is a spherical body, was more and more generally accepted, and was put beyond doubt when the first circumnavigation by the Portuguese Magellan (I5I9) became known, an example followed, at short intervals, by almost all European nations. Thus the idea so generally accepted at a very early period that the figure of the earth must be spherical, was again revived about the end of the seventeenth century. The desire to ascertain, according to the above-described methods the circumference of this circle was also cherished by the ancients, and we have accounts of measurements taken for this purpose in the earliest times, of the most important of which we give some account.

The first determination known to us of the size of the earth was made by Eratosthenes in Alexandria in the third century before Christ. $\mathrm{He}$ observed at the solstice (the time of its greatest northern declination) in Alexandria, the greatest altitude of the sun above the horizon, and it was known that at that time the sun stood when at its greatest altitude, in the zenith at Syene (from which we may conclude that it could be seen in a deep well). Now since the altitude of the sun above the horizon is always equal to $90^{\circ}$ minus its distance from the zenith, he thus required only to subtract the measured height from $90^{\circ}$, and thus found the distance from the zenith to be the fiftieth part of the whole circumference, or $7^{\circ} 12^{\prime}$. According to this process the distance of the two places was regarded as a fiftieth part of the earth's circumference; and as that distance, according to the accounts of travellers, was 5,000 stadia, the whole circumference of the earth was equal to 250,000 stadia. Eratosthenes altered the result to 252,000 stadia, taking for the length of a degree, 700 stadia. Without considering the great inaccuracy of his altitude measurements, there are yet too many other formidable sources of error in this estimate of the earth's circumference, to allow it any claim to much accuracy. First there was the taking for granted that both places lay on the same meridian, which was not the case, since Syene lay three degrees east from Alexandria; and second, the distance of the two places reckoned at 5,000 stadia was too great.

A second investigation was made by Posidonius in the first century before Christ, but his result was still more erroneous than that of Eratosthenes. He observed the height of one of the brightest stars (Canopus in Argo) above the horizon. It reaches, at the time of its culmination at Alexandria, an altitude equal to the forty-eighth part of the circumference, while in Rhodes it was 